\title{
Research in auditing: main themes ${ }^{\star}$
}

\author{
Marcelo Porte \\ Centro Universitário de João Pessoa, Departamento de Gestão Financeira, João Pessoa, PB, Brazil \\ Email: marcelo.porte@unipe.br
}

\section{Irina Saur-Amaral}

Universidade Europeia, Escola de Ciências Sociais e Empresariais, Lisboa, Portugal

Email: irina.amaral@universidadeeuropeia.pt

\section{Carlos Pinho}

Universidade de Aveiro, Departamento de Economia, Gestão, Engenharia Industrial e Turismo, Aveiro, Portugal

Email: cpinho@ua.pt

Received on 10.02.2016 - Desk acceptance on 11.01.2016 - $3^{\text {rd }}$ version approved on 08.03.2017

\begin{abstract}
The passage of the Sarbanes-Oxley Act (SOX) was a turning point in auditing and in auditors practice for the academic world. Research concerning the characterization of academic production related to auditing is in its third decade. Its analysis is accomplished by means of definition of keywords, abstracts or title, and information on thematic association within the academic production itself in auditing is undisclosed. In order to revise this gap in auditing literature, this study identified the main themes in auditing and their association in post-SOX era by analyzing the content of objectives and hypothesis of 1,650 publications in Web of Science (2002-2014). The findings in this study extended those from the study by Lesage and Wechtler (2012) from 16 auditing thematic typologies to 22. The results demonstrate that the themes audit report \& financial statement users, corporate governance, audit market, external audit, socio-economic data of the company, international regulation, and fraud risk \& audit risk were the most addressed in the publications about auditing. Corporate governance has a broader association with the other themes in the area. Future researches may use these themes and relate them to the methodologies applied to audit studies.
\end{abstract}

Keywords: typologies, themes, investigation, audit.

Correspondence address:

Marcelo de Santana Porte

Centro Universitário de João Pessoa, Departamento de Gestão Financeira

Rodovia BR-230, Km 22, s/n - CEP: 58053-000

Água Fria - João Pessoa - PB - Brazil

*The authors thank the financial support received from Coordenação de Aperfeiçoamento Pessoal de Nível Superior (CAPES) and the valuable contribution made by the ad-hoc reviewers for the improvement of this research. 


\section{INTRODUCTION}

Since the precursor work of Smith and Krogstad (1984), expanded by the same authors in later years (1988, 1991), in which they developed a seven category typology, "SK typology", in order to study the academic production about auditing in Auditing: A Journal of Practice \& Theory, researchers have been using its typology to carry out bibliometric and scientometric comparisons in scientific papers. As research on characterization of the academic production in auditing is in its third decade, the following arguments are pertinent: which journals in auditing production are the most relevant? Which themes emerging and which are declining after the Sarbanes-Oxley Act of 2002 (SOX)? How are auditing themes evolving? How are themes associated in auditing publications?

These questions were motivated, at first, by the creation of the SOX that aims "to protect investors, improving precision and reliability of the corporative disclosures in compliance with the law of securities, and for other purposes" (SOX, 2002), which was a turning point to the academic world in auditing study and in auditors practices.

Second, in auditing literature, information on related themes in the academic production is undisclosed, i.e., we know which were the major themes addressed along the years, but we do not know which associations were made between them. After all, as a researcher writes about an audit theme, as, for example, corporate governance, he or she may have it associated with another one of auditing itself, as audit honoraria.

In third place, this research was based on the study of Lesage and Wechtler (2012), over the period from 1926 to 2005, addressing 16 themes on audit investigations. Lesage and Wechtler (2012) expanded the investigations by Maijoor, Meuwissen, and Quadackers (2000), in which they have identified nine themes (from 1990 to 1997), two in addition to the precursor study accomplished by Smith and Krogstad $(1984,1988,1991)$ - responsible for the creation of "SK typology" -, presenting the seven first themes tracked in audit scientific investigation. Therefore, the purpose is to accomplish something not yet seen to the post-SOX era, i.e., a study of themes published in audit based on research objectives and hypothesis through a content analysis. Many researches are carried out based in title, abstract, and keywords (Carcello, Hermanson, \& Ye, 2011; Garcia-Meca \& Sanchez-Ballesta, 2009). However, we know that more than computer aid in finding results, analyzing the articles content and its essence is still a preponderant technique for determining, in a clear and credible manner, the information to be extracted.

This study aims to identify the main themes and their associations in auditing in post-SOX era. Therefore, 1,650 publications in auditing were examined, considering 21 journals between 2002 and 2014, through a content analysis of the research objectives and hypothesis.

In the next section, we will describe the methodological procedures employed in this study. Later, we will present the first part of the results, which consider the main themes addressed in auditing. Consequently, on the second and last part of the results, we will discuss the applications for the findings of the previous section. Finally, we conclude the study with the discussion of its results, limitations, and some implications for future research.

\section{METHOD}

\subsection{Content Analysis Strategy}

Different from studies based on title, keywords, and abstract (Cruz \& Teixeira, 2010; Fetscherin \& Usunier, 2012; Lesage \& Wechtler, 2012; Porte, Saur-Amaral, \& Pinho, 2015; Silva \& Teixeira, 2009; Uysal, 2010), this research is based mainly on the analysis of objectives and hypothesis of the publications indexed in Web of Science from 2002 - year of the signature of the SOX - in the Social Science Citation Index (SSCI) to 2014, by means of a content analysis. The Institute for Scientific Information (ISI) database, Web of Science ${ }^{\mathrm{TM}}$ Core Collection was used as a reference for this research because it is considered one of the most important information sources for scientific investigation, used in many studies as Duan (2011), Kostoff et al. (2007), Kostoff, Tshiteya, Bowles, and Tuunanen (2006), Krogstad and Smith (2003), and Nerur, Rasheed, and Natarajan (2008). The period of the sample initiates in 2002, as a consequence of the worldwide impact in auditing due to the scandals related to Enron financial reports audited by Arthur Andersen's audit, which resulted in SOX enacting, and ends in 2014 since its data was collected in February $18^{\text {th }} 2015$. Therefore, the 2015 articles were not taken into account once that was the ongoing year. 
Table 1 Comparative scope

\begin{tabular}{|c|c|c|c|c|}
\hline \multirow{2}{*}{ Journal } & \multirow{2}{*}{ Abbreviation } & \multirow{2}{*}{ Country } & \multicolumn{2}{|c|}{ Articles } \\
\hline & & & Amount (n) & $\%$ \\
\hline Abacus & ABS & AUS & 32 & 1.9 \\
\hline Accounting and Business Research & ABR & UK & 35 & 2.1 \\
\hline Accounting and Finance & $\mathrm{AF}$ & USA & 56 & 3.4 \\
\hline Accounting Auditing \& Accountability Journal & $\mathrm{AAAJ}$ & AUS & 31 & 1.9 \\
\hline Accounting Horizons & $\mathrm{AH}$ & USA & 79 & 4.8 \\
\hline Accounting Organizations and Society & AOS & UK & 94 & 5.7 \\
\hline Accounting Review & $\mathrm{AR}$ & USA & 178 & 10.8 \\
\hline African Journal of Business Management & AJBM & NIG & 51 & 3.1 \\
\hline Auditing: A Journal of Practice and Theory & AJPT & USA & 330 & 20.0 \\
\hline Australian Accounting Review & AAR & USA & 47 & 2.8 \\
\hline Betriebswirtschaftliche Forschung und Praxis & BFP & GER & 32 & 1.9 \\
\hline Contemporary Accounting Research & CAR & CAN & 171 & 10.4 \\
\hline Corporate Governance: An International Review & CGIR & UK & 65 & 3.9 \\
\hline European Accounting Review & EAR* & UK & 46 & 2.8 \\
\hline Journal of Accounting \& Economics & JAE & USA & 64 & 3.9 \\
\hline Journal of Accounting and Public Policy & JAPP & USA & 67 & 4.1 \\
\hline Journal of Accounting Research & JAR & USA & 64 & 3.9 \\
\hline Journal of Banking \& Finance & JBF & NET & 28 & 1.7 \\
\hline Journal of Business Ethics & JBE & NET & 115 & 7.0 \\
\hline Journal of Business Finance \& Accounting & JBFA & UK & 36 & 2.2 \\
\hline Review of Accounting Studies & RAS & NET & 29 & 1.8 \\
\hline Total & 21 & - & 1,650 & 100.0 \\
\hline
\end{tabular}

Note: Values in bold mean the most relevant representations of the theme.

*EAR is the journal of the European Accounting Association.

Source: Developed by the authors.

The first step was to use the word audit* in order to find its derived terminologies, as audit, auditing, auditor, or auditors in the blank Topic (consisting of title, abstract, and keywords) in the citation index of SSCI. After that procedure, the refined search produced 25,530 results. The second step was to sort out documents into types, separating two groups, Article and Review, thus reducing to 23,416 results. In the third step, the research field Business Economics was selected, as, after a pre-test, this was found to be the closest area to the proposed theme, generating 2,846 results distributed in 385 journals. However, it must be emphasized that, although the search was refined, other areas were taken into account because the same publication may be classified in more than one area. Therefore, in view of an appropriate scope of the research, there were no exclusions made on the new areas resulting from the selection of that group. If we had made such exclusions, we would also exclude publications of Business Economics. The fourth step was to exclude outliers (180). It is important to point out that the outliers identified correspond to the publications that were not associated to auditing or were withdrawn by journals editors. The fifth step was to organize the 2,666 results identified in each publication source. However, 135 journals had only one publication. Therefore, only those corresponding to at least $1 \%$ of the total $($ of 2,666$)$ were selected - meaning that the selected journals had at least 26 publications from 2002 to 2014 -, composing a new database with 1,650 results in 21 journals, as seen in Table 1.

The study of Lesage and Wechtler (2012) was used to guide the cataloguing of the themes. At last, the data was transferred to the quantitative analysis program SPSS for data tabulation and descriptive statistical analysis which concluded the content analysis of the study.

As described in Table 1, the top journals selected in the procedure above were Auditing: A Journal of Practice and Theory (330), Accounting Review (178), and Contemporary Accounting Research (171), in addition to other auditing studies (Bonner, Hesford, Van der Stede, \& Young, 2006; Krogstad \& Smith, 2003; Solomon \& Trotman, 2003). 
These three journals are responsible for not much more than $40 \%$ of the publications in auditing. Since all three journals appear to be relevant to scientific development in this field throughout that period (20022014), they were the highlights of this study's thematic production analysis.

\subsection{Coding Methods}

Due to the large amount of articles analyzed, and aiming to maintain a standard for the comparison of results, initially the 16 typologies identified by Lesage and Wechtler (2012) were used. No exclusions were made on the arising of new typologies resulting from the content analysis carried out.
The first step was to identify the article theme(s) and subjects approached. In that purpose, the research objectives and hypothesis were examined in each article, relating its theme to the 16 typologies of Lesage and Wechtler (2012). If the theme was not compatible with any of the predetermined typologies, it would be related to a new typology related to its theme.

It is worth mentioning that, in a different way from the studies referred before, this work aims to identify all themes by article, given that many among them comprehend more than one theme in auditing.

This complete systematic procedure was accomplished to the effect that the questions (Figure 1) were answered with maximum scientific rigor.

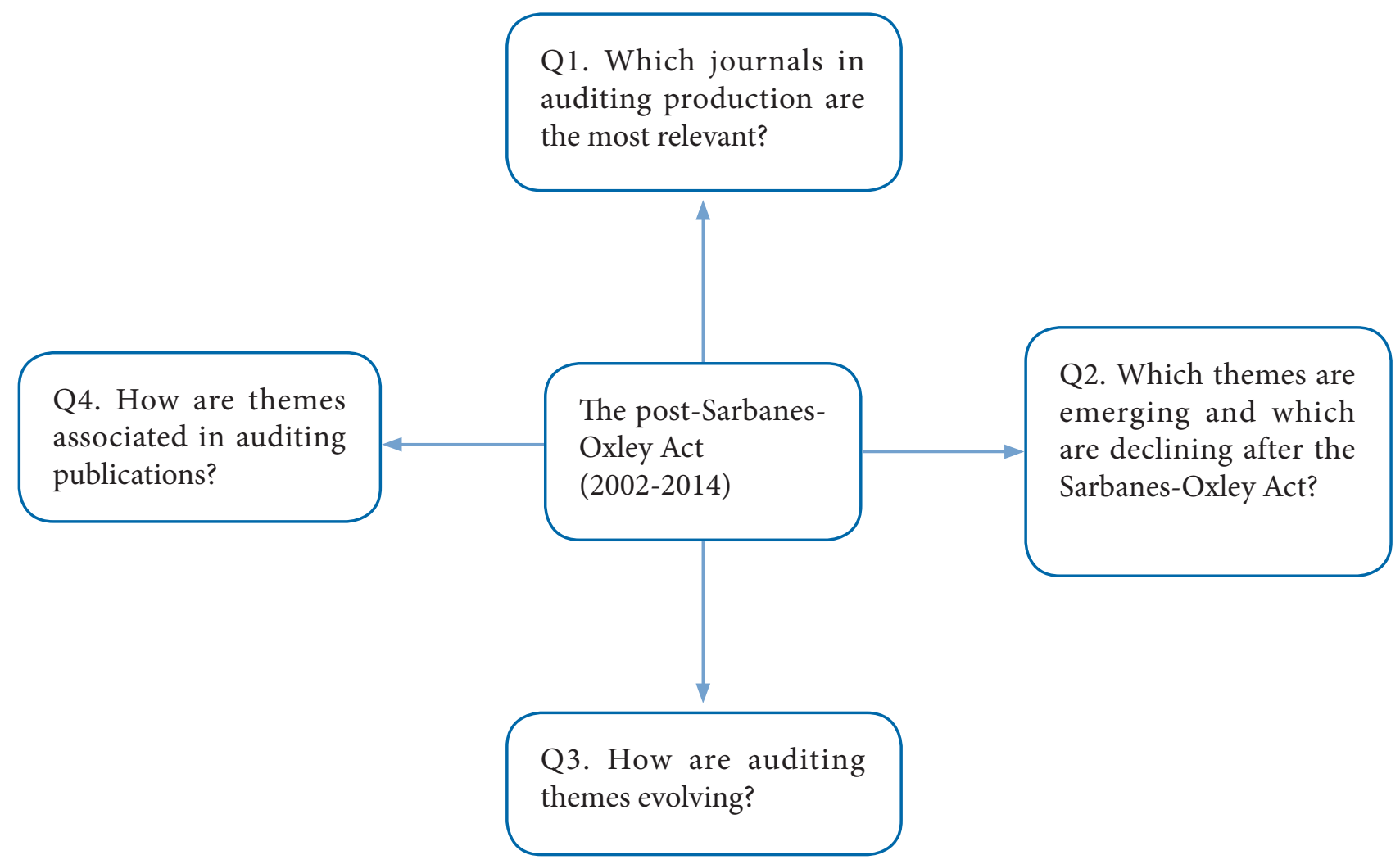

Figure 1 Research questions

Source: Developed by the authors. 


\section{AUDIT PRODUCTION CHARACTERISTICS}

First, we will present the evolution of the production in auditing between 2002 and 2014. Then, we will compare the results found in this research and those of Lesage and Wechtler (2012) with respect to auditing themes.

\subsection{Evolution}

We noticed that, in the course of the years, the academic investigative production in auditing (Figure 2) has increased, reaching its highest levels in 2011 and then again in 2013, thus showing its significance to the scientific development in the field of study. Results found by Lesage and Wechtler (2012), which present decreasing data over the next three years after the SOX passage, have been questioned, because this study confirms that during the same period (2003-2005) the production in auditing was practically the same.

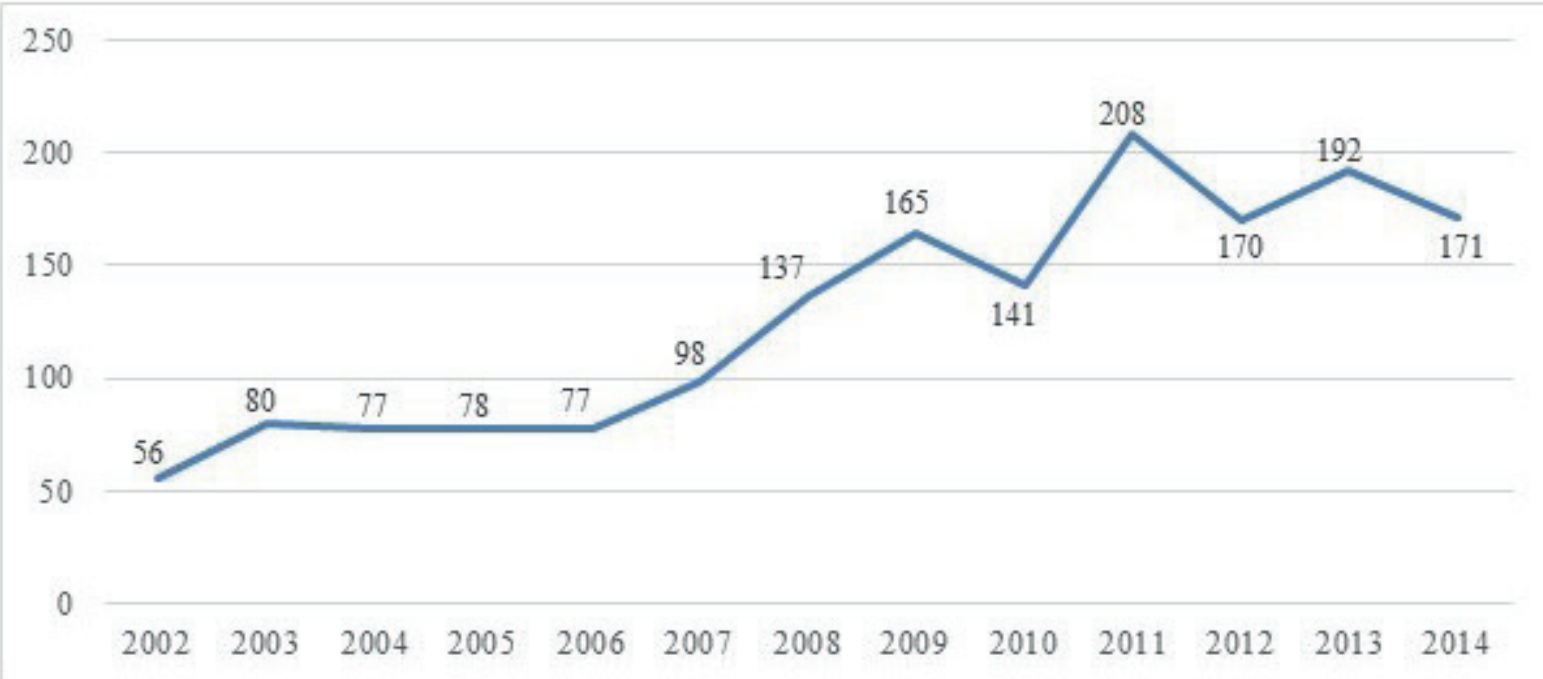

Figure 2 Quantity of audit papers 2002-2014

Source: Developed by the authors.

\subsection{Themes in Auditing}

This work extended the studies on themes in auditing, especially the one of Lesage and Wechtler (2012), from 16 to 22 themes in auditing. The study replaces the theme auditor-client relationship by seven new themes identified: audit committee, external audit, internal audit, internal control, media coverage in accounting, research, and socio-economic data of the company. The thematic classification was not limited to identifying just one theme by publication, because the objectives or hypotheses of the analyzed works consisted in articles that could contemplate, as an example, the analysis of internal audit quality and of fraud risk - more than one theme in the same study.

\subsubsection{Established themes.}

Between the 22 themes identified in this study's results, seven have been rated as established. This establishment occurred because those themes were in evidence before, in the work of Lesage and Wechtler (2012), and because they demonstrated higher percentages when compared to the aforementioned work. In addition, they are present in every year (2002 to 2014) used in this research's sampling.

The first theme to be explained is audit market. The papers refer to factors associated to firms in the audit market. As an example we can point to establishment of audit firms, studies related to audit firms (big audit firms and smaller ones), audit fees, fees awarded for audit services, factors concerning mandatory rotation of the 
audit firm, the monopoly of audit firms, and joint audit between audit firms (Caramanis, 2005; Carson, Redmayne, \& Liao, 2014; Choi, Kim, Liu, \& Simunic, 2008; De Franco, Gavious, Jin, \& Richardson, 2011; Elliott, Ghosh, \& Peltier, 2013).This theme had a result seven times higher and it is third in representativeness (27.6\%), present during the whole project's period and in all journals.

Second is the theme audit report \& financial statement users. This theme presents papers referring to factors concerning audit reports and the impacts that may affect the clients of the financial statements. As an example we list the analysis about fair value, as compulsory and voluntary disclosures, adjustments and errors existing in the financial statements, disclosure of financial reports in the internet, and presentation of transparency report (Athanasakou \& Hussainey, 2014; Carcello \& Li, 2013; Chen, Elder, \& Hung, 2014; Chi, Dhaliwal, Li, \& Lin, 2013; Luypaert \& Van Caneghem, 2014). More than doubled, becoming the most identified in this area (36.3\%) and it appears every year and all publications.

Thereupon, the third theme refers to corporate governance. The papers on the subject analyze connections with the process of corporate governance in the organizational world, at equally private, public, and nonprofit organizations. As examples, we point out business performance, management earnings, salaries of the high-rank company members, changes in management, cost of capital, directors' connection to the audit committee, voluntary auditing requested by managers, and channels to disclose fraud. The subjects addressed are related to factors of corporate governance of the auditors' client, as management of results, capital cost, administrative board, and CEO (Azizkhani, Monroe, \& Shailer, 2010; Haw, Ho, \& Li, 2011; Johnson, Kuhn, Apostolou, \& Hassell, 2013; Lim, 2011). It is the second higher percentage (34.4\%) and it increased nine times, identified in all years and journals of the study.

The fourth theme is fraud risk \& audit risk. In this matter, there are papers related to fraud risk in audited companies and to other risks in which audit firms undergo in delivering their services. Contents in this area: fraud, misstatement risk, time estimated by the auditor for task accomplishment at clients company, audit methodologies, and accounting errors identified by the auditor (Trompeter, Carpenter, Jones, \& Riley, 2014; Young \& Peng, 2013). A theme that has increased almost six times compared to the previous data (16.7\%), present in every year and all journals.

The fifth established theme is international regulation. It refers to the papers addressing aspects concerning legal regulations that define guidelines in auditing.
We can give as examples applying and implementing rules for financial statement disclosure, code of ethics, regulatory authority, legal aspects concerning stakeholder protection, and legal responsibility of the companies (De George, Ferguson, \& Spear, 2013; Gul, Zhou, \& Zhu, 2013; Mennicken, 2008). More than tripled when compared to the last study (17.6\%), comprehending the whole period and all journals.

Second to last is liability \& litigation, which presents papers involving the legal responsibilities of the auditor and the factors related to litigation between auditor and client, as in risk litigation, insurance hypothesis, sanctions imposed on audit firms, auditor reputation, and cost litigation (Bigus, 2012; Boone, Khurana, \& Raman, 2011; Kanagaretnam, Krishnan, \& Lobo, 2009; Li, 2009; Tarr \& Mack, 2013). Percentage tripled in this research (9\%) and present in all the years in 19-21 journals.

Finally, the theme non-audit services reveals papers concerning specifically services rendered by audit firms that are not classified as external audit services, for example, partner tenure, information about fees, consulting, and auditor tenure (Cahan, Emanuel, Hay, \& Wong, 2008; Habib, 2012; Koh, Rajgopal, \& Srinivasan, 2013). More than doubled its percentage (5.1\%), present in all years and in 18-21 journals.

\subsubsection{Declining themes.}

Assessing themes in decline, we found eight classified in that situation. The present classification is valid if we take into account they have decreased in representativeness when compared to the previous study carried out by Lesage and Wechtler (2012).

The first theme explained in this section is audit procedures. It consists of papers related to the procedures used by audit firms in the accomplishment of their services. We can point out audit team brainstorming, analytical procedures, quality of paperwork, assessment face-toface of paperwork, electronic evaluation of paperwork, work plan, and digital analysis (Bhattacharjee, Moreno, \& Riley, 2012; Lynch, Murthy, \& Engle, 2009; Trompeter $\&$ Wright, 2010). This theme had a decrease of $24 \%$ on its representativeness (5.3\%) and it was published every year of the study, just in 10-21 journals.

Secondly, we will discuss audit sampling. This theme presents papers that study, specifically, the selection process of the sample to be audited, used by audit firms during their services. We may cite sample size, error projection rates, mathematical programming models, and probability-proportional-to-size (Elder, Akresh, Glover, Higgs, \& Liljegren, 2013; Mauldin \& Wolfe, 2014). Its representativeness decreased in $80 \%(0.8 \%)$, being present in 9-13 years of the study and in 7-21 publications. 
Subsequent, the third theme is auditor's judgment. It refers to papers that approach subjective factors, which may influence the auditor's judgment in the process of the auditing service. As examples we may point out the existence or lack of materiality, auditors' mood, evaluate competence of subordinates/audit pairs, and tasks implementation (Cianci \& Bierstaker, 2009; Luippold \& Kida, 2012; Pike, Curtis, \& Chui, 2013). It decreased in emphasis almost by half $(6.8 \%)$, despite its presence during all the research period, and was found in 13-21 publications.

The fourth theme is auditor-auditee contract. It was identified in two publications and it is related to audit contract (Frederickson \& Waller, 2005; Jensen \& Payne, 2005). This theme had no significant values, present only in 2005 and in a small percentage $(0.1 \%)$, very different from the results in comparison.

The fifth theme in decline is education. As elements of this theme we found articles which stress subjects concerning auditors' education, as hours of study, e-learning, scientific production, master of business administration (MBA), and plagiarism (Allen \& Woodland, 2010; Cheng, 2011; Free, Salterio, \& Shearer, 2009; Koh, Scully, \& Woodliff, 2011; Stephens, Summers, Williams, $\&$ Wood, 2011). There was a decrease in notability in more than $90 \%(0.5 \%)$. Only $5-13$ of the years surveyed were issued and in only 6-21 newspapers.

The sixth theme is going-concern opinion. Papers on this theme discuss factors involving the auditor's opinion when issuing reports about the clients' capability to continue with their businesses' activities, such as opinion of continuity, feasibility, and continuation with clients activities (Amin, Krishnan, \& Yang, 2014; Blay, Geiger, \& North, 2011; Kaplan \& Williams, 2013). There was a decrease of $25 \%$ regarding its importance in auditing $(4.5 \%)$, in spite of its presence in the whole period of the study and in 16-21 journals.

Second to last theme is profession. This theme presents papers which bring evidence of professional aspects of the auditors. As examples we point out auditors specialization in a market segment, as the banking or industrial, level of experience, age, educational background, expert sustainability, and actuarial (Carrera \& Carmona, 2013; Chin, Yao, \& Liu, 2014; Dalton, Buchheit, \& McMillan, 2014; Ladva \& Andrew, 2014). There was a decrease of $10 \%$ its importance in auditing (9.9\%) and it was evident during the whole period in 20-21 journals.

Finally, the eighth theme is tax audit, presenting papers related to audit tax services of auditing firms. For example, double taxation, billing rates, tax law, tax services, and tax incentives (De Waegenaere, Sansing, \& Wielhouwer,
2006; Robinson, 2008). There was a decrease of $5 \%$ on its importance in auditing (1.9\%) and it is present in 11-13 years researched and in 12-21 journals.

\subsubsection{Emerging themes.}

As regarding emerging themes, seven were classified in this perspective. It is important highlight that it was the first time that these themes were described in a research about auditing.

The first theme for discussion is audit committee. In this subject, we group papers which assess subjects related to the unity of the audit committee of companies that may go through external audit, regardless of being a private, public, or nonprofit company. As examples, we point out knowledge of the financial area, its independence, size, efficacy, role of the committee, tenure of independent member, and legal experience (Badolato, Donelson, \& Ege, 2014; Carcello, Neal, Palmrose, \& Scholz, 2011; Choi, Han, \& Lee, 2014; Sharma \& Iselin, 2012). It is a new theme emerged from corporate governance which immediately proved to be of great representativeness (11\%), being present in the whole project's duration (2002-2014) and in each of the 21 journals.

The second theme is external audit. It presents papers related to audit services and the relationship between the auditor and his/her client during the external audit. We emphasize on this matter the audit services quality, the auditor's independence, customer bargaining power, delay in the work, value-added, assurance service, dismissal/ resignation of the auditor, ethics, and auditor-client relationships (Conroy, Emerson, \& Pons, 2010; Gu, 2013; Rennie, Kopp, \& Lemon, 2010; Saito \& McIntosh, 2010). It is a new theme, which has the third higher score, with the same result of audit market (27.6\%). It appears in the whole period and all journals.

Thereupon, the third theme is internal audit. This theme concerns papers which describe studies about the internal audit unit of companies susceptible to audit, regardless of being a private, public, or nonprofit company. As examples we refer to outsourcing of internal audit, continuous monitoring, accounting knowledge, performance, competence, investment, management training ground, experience, ethics, and effectiveness (Alic \& Rusjan, 2011; Cohen \& Sayag, 2010; Desai, Roberts, \& Srivastava, 2010; Prawitt, Sharp, \& Wood, 2012). It is a new theme not previously identified as showing its relevance (4.1\%). It is included in every year of the research, except for 2006, and published in 14-21 publications.

The fourth theme in debate is internal control. In this theme, the papers relate to internal control unit of companies susceptible to audit, regardless of being a private, public, or nonprofit company. The subthemes are as 
follows: internal control deficiencies, material weaknesses, volunteer management reporting, effectiveness, human resources, quality, information technology, public reporting, cost, power, reliability, training, transfer of information to the auditor, investment, and efficiency (Bedard \& Graham, 2011; Choi, Choi, Hogan, \& Lee, 2013; Ettredge, Li, \& Sun, 2006; Krishnan, Rama, \& Zhang, 2008). It is a new theme not previously described and it emerges with a good representativeness (6\%), present in 11-13 years of the research and in 17-21 journals.

The fifth emerging theme is media coverage in accounting, which presents papers connected to news coverage about matters on the company's accounting office, whether private, public, or nonprofit companies. For example, scandal exposure by the press, disclosure of financial reports by the companies in printed press, and information about the company's image (Andon \& Free, 2014; Dee, Lulseged, \& Zhang, 2011). It is a new theme that emerges in a gradual manner $(0.8 \%)$, present in $8-13$ years and in 8-21 journals.

The second to last theme to be presented is research, in which we determined the existence of papers object of analysis for the understanding of the development of scientific dynamics and of thematic areas. As examples we point out the study of literature review in auditing, thematic, bibliometry, and research methodology (Cram, Karan, \& Stuart, 2009; Lesage \& Wechtler, 2012; Napier, 2006; Uysal, 2010). It is a new theme identified by the research, revealing its relevance (3.3\%). It appears during the whole period in 15-21 journals.

Finally, the last theme is socio-economic data of the company, which presents papers assessing the economic and social aspects of the companies, whether public, private, or nonprofit. For example, its size, family companies, company age, operational complexity, pay higher wages, location, insolvency, company value, and classification aspects as public, private, and nonprofit (Carson \& Fargher, 2007; Choi, Kim, Qiu, \& Zang, 2012; Clatworthy \& Peel, 2013; Humphrey \& Miller, 2012; Vermeer, Edmonds, \& Asthana, 2014). A new theme not previously identified, showing its significance in the field (19.5\%). It is present in the whole period and in all journals.

This chapter presented the themes established, declining and emerging in auditing, besides updating the thematic importance collected in the analysis of more than one decade of the post-SOX era in scientific research.

\section{APPLICATIONS}

Now the thematic trends in audit research will be presented, as well as the thematic contribution of each journal, highlighting the Auditing: A Journal of Practice \& Theory, Accounting Review and Contemporary Accounting Research, and followed by the association of themes in auditing.

\subsection{Thematic Trends on Audit Research}

The audit market has suffered a significant change after the passage of the SOX and it would be no different, considering the impacts on scientific research in the area. Proof of that is an increasing academic production in auditing from 2002 to 2014 illustrated on Figure 2. Lesage and Wechtler (2012) state that the "SK typology" proposed by Smith and Krogstad (1984) is deficient because it is over 30 years old, so it does not reflect the present themes in auditing due to the changes occurred in this field. Notwithstanding the important contribution of Lesage and Wechtler (2012), they grounded their work on thematic trends in auditing in pre-SOX era, having extended their research until 2005. Even though analyzing the short postSOX period, their results were not representative of the themes in auditing after SOX enactment. This study fills this gap left by the authors and introduces a new topic on audit research - the association of themes in auditing.

Table 2 presents the themes identified in the research and their impact over the years. The horizontal analysis highlights the three most relevant representations of the theme, in a shading off effect, and it demonstrates the evident decrease of the theme during this time (darker for greater amount).

As may be seen in Table 2, the time from 2011 to 2014 was significant to 19 themes, except to auditor's judgment, auditor-auditee contract, internal audit, and non-audit services, that is, during this period, themes reached their highest level in publication, demonstrating that such themes have been much discussed by researchers recently. The theme non-audit services had a soft decrease and the theme auditor-auditee contract, accredited by a previous research, lost expression in time until there was no more mention of it since 2005 . 
Table 2 Popularity of themes on audit research

\begin{tabular}{|c|c|c|c|c|c|c|c|c|c|c|c|c|c|c|}
\hline Themes & 2002 & 2003 & 2004 & 2005 & 2006 & 2007 & 2008 & 2009 & 2010 & 2011 & 2012 & 2013 & 2014 & Total \\
\hline Audit committee & 6 & 9 & 9 & 12 & 6 & 14 & 19 & 18 & 12 & 17 & 15 & 22 & 22 & 181 \\
\hline Audit market & 14 & 22 & 19 & 30 & 25 & 27 & 37 & 40 & 32 & 49 & 46 & 50 & 65 & 456 \\
\hline Audit procedures & 4 & 7 & 7 & 4 & 4 & 6 & 7 & 9 & 10 & 12 & 7 & 6 & 4 & 87 \\
\hline $\begin{array}{l}\text { Audit report \& financial } \\
\text { statement users }\end{array}$ & 24 & 27 & 30 & 30 & 27 & 31 & 57 & 61 & 42 & 79 & 61 & 66 & 64 & 599 \\
\hline Audit sampling & 0 & 1 & 1 & 1 & 0 & 0 & 2 & 1 & 1 & 0 & 1 & 3 & 3 & 14 \\
\hline Auditor's judgment & 7 & 13 & 3 & 9 & 6 & 8 & 10 & 11 & 7 & 11 & 11 & 11 & 5 & 112 \\
\hline Auditor-auditee contract & 0 & 0 & 0 & 2 & 0 & 0 & 0 & 0 & 0 & 0 & 0 & 0 & 0 & 2 \\
\hline Corporate governance & 18 & 18 & 26 & 29 & 21 & 35 & 57 & 61 & 44 & 77 & 63 & 61 & 58 & 568 \\
\hline Education & 0 & 0 & 1 & 0 & 0 & 0 & 0 & 2 & 1 & 3 & 0 & 1 & 0 & 8 \\
\hline External audit & 15 & 26 & 22 & 17 & 24 & 28 & 34 & 43 & 46 & 62 & 53 & 53 & 33 & 456 \\
\hline Fraud risk \& audit risk & 11 & 16 & 11 & 14 & 10 & 18 & 22 & 27 & 28 & 37 & 22 & 29 & 31 & 276 \\
\hline Going-concern opinion & 3 & 4 & 3 & 4 & 3 & 4 & 9 & 8 & 6 & 7 & 5 & 11 & 7 & 74 \\
\hline Internal audit & 1 & 2 & 5 & 1 & 0 & 3 & 6 & 10 & 8 & 9 & 8 & 8 & 6 & 67 \\
\hline Internal control & 0 & 1 & 0 & 1 & 4 & 7 & 12 & 14 & 6 & 18 & 15 & 15 & 6 & 99 \\
\hline International regulation & 4 & 10 & 6 & 15 & 13 & 13 & 21 & 26 & 34 & 35 & 31 & 48 & 34 & 290 \\
\hline Liability \& litigation & 9 & 7 & 6 & 13 & 9 & 9 & 8 & 13 & 17 & 13 & 19 & 17 & 8 & 148 \\
\hline Media coverage in accounting & 0 & 1 & 0 & 1 & 2 & 0 & 1 & 0 & 1 & 2 & 3 & 0 & 2 & 13 \\
\hline Non-audit services & 3 & 7 & 8 & 4 & 11 & 7 & 5 & 8 & 4 & 6 & 6 & 8 & 7 & 84 \\
\hline Profession & 8 & 8 & 6 & 8 & 4 & 11 & 10 & 16 & 15 & 27 & 15 & 15 & 20 & 163 \\
\hline Research & 2 & 2 & 1 & 1 & 3 & 2 & 3 & 5 & 5 & 8 & 8 & 9 & 6 & 55 \\
\hline $\begin{array}{l}\text { Socio-economic data } \\
\text { of the company }\end{array}$ & 6 & 9 & 11 & 10 & 15 & 25 & 25 & 25 & 24 & 54 & 40 & 47 & 30 & 321 \\
\hline Tax audit & 0 & 2 & 3 & 0 & 4 & 3 & 2 & 1 & 1 & 3 & 5 & 2 & 5 & 31 \\
\hline Total & 56 & 80 & 77 & 78 & 77 & 98 & 137 & 165 & 141 & 208 & 170 & 192 & 171 & 1,650 \\
\hline
\end{tabular}

Note: Values in bold mean the most relevant representations of the theme. Source: Developed by the authors.

Of the studied themes, audit report \& financial statement users (599), corporate governance (568), audit market (456), external audit (456), socio-economic data of the company (321), international regulation (290), and fraud risk \& audit risk (276) were the most significant in auditing. Particularly, 2011 was a prominent year, with 10 themes and the highest number of publications.

\subsection{Thematic Contribute of Journals}

Table 3 presents the major contributions of the scientific journals for each theme identified in the research. The three biggest representations of the theme in the scientific journals are highlighted by the use of shading off effect, demonstrating reduction of theme evidence during time (the darker the higher quantity). 
Table 3 Most contributory journals

\begin{tabular}{|c|c|c|c|c|c|c|c|c|c|c|c|c|c|c|c|c|c|c|c|c|c|c|}
\hline $\begin{array}{l}\text { Themes } \\
\text { (Abbrev.) }\end{array}$ & $\begin{array}{l}\text { A } \\
\text { B } \\
\text { S }\end{array}$ & $\begin{array}{l}\text { A } \\
\mathbf{B} \\
\mathbf{R}\end{array}$ & $\begin{array}{l}A \\
F\end{array}$ & $\begin{array}{c}\text { A } \\
\text { A } \\
\text { A } \\
\text { J }\end{array}$ & $\begin{array}{l}\mathbf{A} \\
\mathbf{H}\end{array}$ & $\begin{array}{l}\mathbf{A} \\
\mathrm{O} \\
\mathrm{S}\end{array}$ & $\begin{array}{l}\mathbf{A} \\
\mathbf{R}\end{array}$ & $\begin{array}{c}\mathbf{A} \\
\mathbf{J} \\
\mathbf{B} \\
\mathbf{M}\end{array}$ & $\begin{array}{l}\mathbf{A} \\
\mathbf{J} \\
\mathbf{P} \\
\mathbf{T}\end{array}$ & $\begin{array}{l}\mathbf{A} \\
\mathbf{A} \\
\mathbf{R}\end{array}$ & $\begin{array}{l}\mathbf{B} \\
\mathbf{F} \\
\mathbf{P}\end{array}$ & $\begin{array}{l}\text { C } \\
\text { A } \\
\text { R }\end{array}$ & $\begin{array}{l}\mathbf{C} \\
\mathbf{G} \\
\mathbf{I} \\
\mathbf{R}\end{array}$ & $\begin{array}{l}\mathbf{E} \\
\mathbf{A} \\
\mathbf{R}\end{array}$ & $\begin{array}{l}\mathbf{J} \\
\mathbf{A} \\
\mathbf{E}\end{array}$ & $\begin{array}{l}\mathbf{J} \\
\mathbf{A} \\
\mathbf{P} \\
\mathbf{P}\end{array}$ & $\begin{array}{l}\mathbf{J} \\
\mathbf{A} \\
\mathbf{R}\end{array}$ & $\begin{array}{l}\text { J } \\
\text { B } \\
\text { F }\end{array}$ & $\begin{array}{l}\text { J } \\
\text { B } \\
\text { E }\end{array}$ & $\begin{array}{l}\mathbf{J} \\
\mathbf{B} \\
\mathbf{F} \\
\mathbf{A}\end{array}$ & $\begin{array}{l}\mathbf{R} \\
\mathbf{A} \\
\mathbf{S}\end{array}$ & Total \\
\hline ACOM & 1 & 6 & 8 & 1 & 5 & 5 & 24 & 4 & 25 & 10 & 1 & 16 & 23 & 7 & 4 & 13 & 4 & 4 & 10 & 8 & 2 & 181 \\
\hline MRKT & 7 & 12 & 20 & 2 & 27 & 14 & 52 & 6 & 118 & 9 & 2 & 63 & 6 & 13 & 20 & 26 & 22 & 8 & 7 & 11 & 11 & 456 \\
\hline PROC & 1 & 0 & 1 & 0 & 2 & 4 & 17 & 0 & 46 & 0 & 1 & 13 & 0 & 1 & 0 & 0 & 1 & 0 & 0 & 0 & 0 & 87 \\
\hline REPO & 16 & 12 & 20 & 6 & 36 & 19 & 72 & 21 & 96 & 19 & 8 & 61 & 17 & 19 & 28 & 39 & 30 & 8 & 36 & 20 & 16 & 599 \\
\hline SAMP & 0 & 0 & 0 & 0 & 2 & 0 & 1 & 0 & 7 & 0 & 1 & 1 & 0 & 0 & 0 & 1 & 0 & 0 & 1 & 0 & 0 & 14 \\
\hline JUDG & 0 & 3 & 4 & 0 & 3 & 7 & 24 & 0 & 37 & 0 & 1 & 14 & 0 & 1 & 0 & 2 & 6 & 0 & 9 & 0 & 1 & 112 \\
\hline CONT & 0 & 0 & 0 & 0 & 0 & 0 & 0 & 0 & 1 & 0 & 0 & 0 & 0 & 0 & 0 & 0 & 1 & 0 & 0 & 0 & 0 & 2 \\
\hline CGOV & 4 & 10 & 26 & 6 & 18 & 25 & 54 & 27 & 57 & 13 & 4 & 61 & 57 & 14 & 30 & 27 & 23 & 21 & 59 & 21 & 11 & 568 \\
\hline EDUC & 0 & 0 & 1 & 0 & 1 & 1 & 0 & 1 & 1 & 0 & 0 & 0 & 0 & 0 & 0 & 0 & 0 & 0 & 3 & 0 & 0 & 8 \\
\hline EXTE & 3 & 12 & 12 & 4 & 22 & 26 & 57 & 7 & 112 & 15 & 7 & 51 & 3 & 13 & 12 & 18 & 19 & 4 & 49 & 6 & 4 & 456 \\
\hline RISK & 7 & 2 & 6 & 1 & 16 & 26 & 32 & 4 & 65 & 4 & 7 & 29 & 5 & 2 & 4 & 8 & 20 & 4 & 21 & 7 & 6 & 276 \\
\hline GCOP & 2 & 0 & 4 & 0 & 3 & 3 & 9 & 0 & 26 & 2 & 1 & 8 & 1 & 1 & 3 & 3 & 5 & 0 & 2 & 0 & 1 & 74 \\
\hline INTE & 0 & 1 & 6 & 1 & 4 & 3 & 5 & 14 & 13 & 3 & 4 & 7 & 2 & 0 & 0 & 2 & 0 & 0 & 2 & 0 & 0 & 67 \\
\hline ICON & 0 & 0 & 0 & 0 & 11 & 1 & 13 & 2 & 28 & 1 & 1 & 11 & 2 & 2 & 9 & 4 & 4 & 3 & 2 & 2 & 3 & 99 \\
\hline INTR & 13 & 7 & 6 & 9 & 30 & 14 & 27 & 6 & 50 & 12 & 7 & 15 & 6 & 12 & 18 & 20 & 11 & 4 & 14 & 5 & 4 & 290 \\
\hline LTIG & 0 & 1 & 0 & 2 & 5 & 4 & 19 & 4 & 39 & 1 & 1 & 23 & 1 & 6 & 6 & 9 & 9 & 5 & 7 & 1 & 5 & 148 \\
\hline MEDI & 0 & 0 & 1 & 2 & 0 & 1 & 1 & 0 & 0 & 1 & 0 & 3 & 0 & 0 & 0 & 1 & 3 & 0 & 0 & 0 & 0 & 13 \\
\hline NAS & 2 & 1 & 4 & 0 & 1 & 2 & 11 & 0 & 25 & 1 & 2 & 15 & 2 & 1 & 2 & 2 & 6 & 0 & 1 & 4 & 2 & 84 \\
\hline PROF & 1 & 2 & 7 & 8 & 11 & 15 & 18 & 2 & 51 & 3 & 2 & 12 & 0 & 1 & 2 & 1 & 5 & 6 & 12 & 1 & 3 & 163 \\
\hline RESE & 0 & 1 & 2 & 4 & 4 & 8 & 1 & 1 & 16 & 2 & 1 & 3 & 2 & 3 & 3 & 0 & 0 & 0 & 4 & 0 & 0 & 55 \\
\hline SEDC & 7 & 10 & 11 & 6 & 16 & 13 & 22 & 15 & 58 & 15 & 2 & 24 & 21 & 17 & 14 & 17 & 12 & 16 & 13 & 6 & 6 & 321 \\
\hline TAX & 1 & 0 & 0 & 1 & 2 & 1 & 10 & 1 & 1 & 0 & 0 & 7 & 0 & 0 & 0 & 1 & 1 & 0 & 3 & 2 & 0 & 31 \\
\hline Total & 32 & 35 & 56 & 31 & 79 & 94 & 178 & 51 & 330 & 47 & 32 & 171 & 65 & 46 & 64 & 67 & 64 & 28 & 115 & 36 & 29 & 1650 \\
\hline
\end{tabular}

Notes: Themes and abbreviations are described in the text; values in bold mean the most relevant representations of the theme.

Source: Developed by the authors.

There is evidence of publication from Auditing: $A$ Journal of Practice \& Theory on most of the themes in audit (21-22 themes), followed by Contemporary Accounting Research (20-22), and next by Accounting Review (1922). Those three journals are responsible for taking the leadership in 19-22 of the identified themes; the other journals have a smaller sampling per area, though not meaning they are less important to scientific development in auditing.

Because of Auditing: A Journal of Practice \& Theory, Accounting Review, and Contemporary Accounting Research are the journals with the highest number of publications in auditing, an analysis of each journal was carried out comprehending annual production volume and published themes in auditing (as may be seen in figures 3, 4, and 5). Auditing: A Journal of Practice \& Theory showed the highest number of publications in auditing between 2002 and 2014. As illustrated in Figure 3 , annually, this journal is responsible for publishing an average of 16 themes in auditing.

It is the leading journal contributing with 16 themes in auditing (Table 3 ), of which are prominent: audit market (MRKT), audit procedures (PROC), audit report \& financial statement users (REPO), corporate governance (CGOV), external audit (EXTE), fraud risk $\&$ audit risk (RISK), international regulation (INTR), profession (PROF), and socio-economic data of the company (SEDC). All those themes are present in every year's publications (Figure 3). 


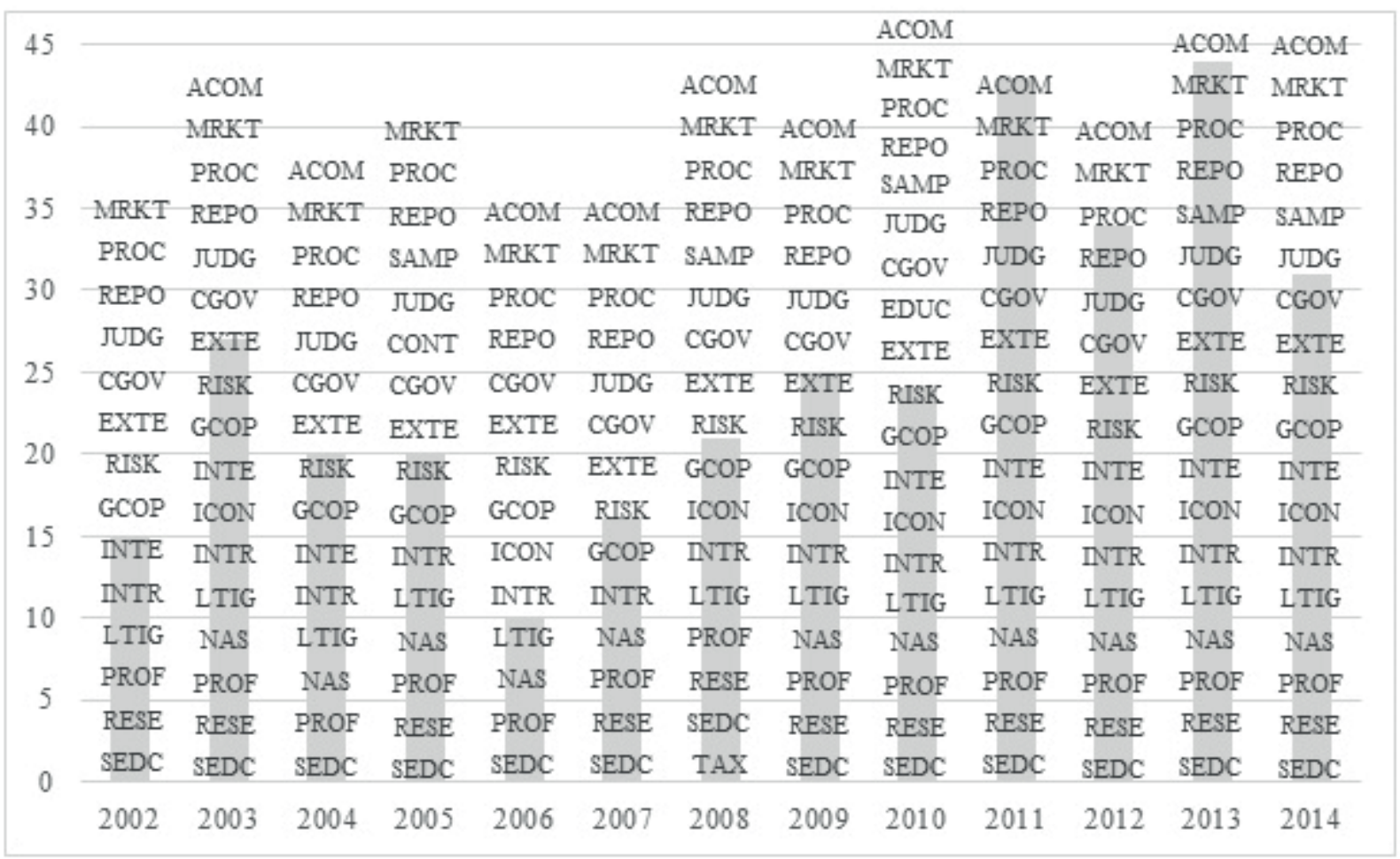

Figure 3 Production in volume (by theme) - Auditing: A Journal of Practice \& Theory Note: Themes are described in the text.

Source: Developed by the authors.

Accounting Review has the second highest academic contributed to tax audit (TAX), as seen in Table 3, with production in auditing. It was the journal that most an average of 13 themes published per year (Figure 4).

\begin{tabular}{|c|c|c|c|c|c|c|c|c|c|c|c|c|c|}
\hline \multirow{4}{*}{20} & & & & & $\mathrm{ACOM}$ & & & $\mathrm{ACOM}$ & & & & ACOM & $\mathrm{ACOM}$ \\
\hline & & & & & MRKT & $\mathrm{ACOM}$ & & MRKT & $\mathrm{ACOM}$ & & $\mathrm{ACOM}$ & MRKT & MRKT \\
\hline & & & $\mathrm{ACOM}$ & & PROC & MRKT & & PROC & MRKT & $\mathrm{ACOM}$ & MRKT & PROC & PROC \\
\hline & & ACOM & MRKT & & REPO & PROC & & REPO & PROC & MRKT & REPO & REPO & REPO \\
\hline \multirow{4}{*}{15} & $\mathrm{ACOM}$ & MRKT & PROC & $\mathrm{ACOM}$ & $\pi \mathrm{DG}$ & REPO & MRKT & $\pi \mathrm{JDG}$ & REPO & PROC & $\pi U D G$ & JUDG & $\pi$ JDG \\
\hline & MRKT & PROC & REPO & MRKT & CGOV & $\pi D G$ & REPO & CGOV & $\pi D G$ & REPO & CGOV & CGOV & CGOV \\
\hline & REPO & REPO & CGOV & REPO & EXTE & CGOV & JUG & EXTE & CGOV & CGOV & EXTE & EXTE & EXTE \\
\hline & $\pi \mathrm{JDG}$ & SAMP & EXTE & $\pi \mathrm{UDG}$ & RISK & EXTE & CGOV & RISK & EXTE & EXTE & RISK & RISK & RISK \\
\hline \multirow{3}{*}{10} & CGOV & JUDG & RISK & CGOV & GCOP & RISK & EXTE & GCOP & RISK & RISK & INTR & GCOP & INTR \\
\hline & EXTE & CGOV & GCOP & EXTE & INTR & INTE & RISK & INTE & GCOP & INTE & LTIG & INTR & LTIG \\
\hline & RISK & EXTE & LTIG & RISK & LTIG & ICON & INTE & ICON & ICON & ICON & NAS & LTIG & MEDI \\
\hline \multirow{4}{*}{5} & GCOP & RISK & NAS & ICON & NAS & INTR & ICON & INTR & INTR & INTR & PROF & NAS & NAS \\
\hline & INTR & GCOP & PROF & INTR & PROF & LTIG & LTIG & NAS & LTIG & LTIG & RESE & PROF & PROF \\
\hline & LTIG & NAS & SEDC & LTIG & SEDC & NAS & PROF & PROF & SEDC & PROF & SEDC & SEDC & SEDC \\
\hline & NAS & PROF & TAX & PROF & TAX & TAX & SEDC & SEDC & TAX & SEDC & TAX & TAX & TAX \\
\hline 0 & 2002 & 2003 & 2004 & 2005 & 2006 & 2007 & 2008 & 2009 & 2010 & 2011 & 2012 & 2013 & 2014 \\
\hline
\end{tabular}

Figure 4 Production in volume (by theme) - Accounting Review

Note: Themes are described in the text.

Source: Developed by the authors. 
Contemporary Accounting Research stands out as the third journal with the highest number of researches in auditing, taking lead in two particular themes (Table 3): corporate governance (CGOV) and media coverage in accounting (MEDI). It includes an average of 13 themes published annually. Accounting Review and Contemporary
Accounting Research had the same highlights over the years comprehending the themes (figures 4 and 5): audit market (MRKT), audit report \& financial statement users (REPO), corporate governance (CGOV), external audit (EXTE), and fraud risk \& audit risk (RISK).

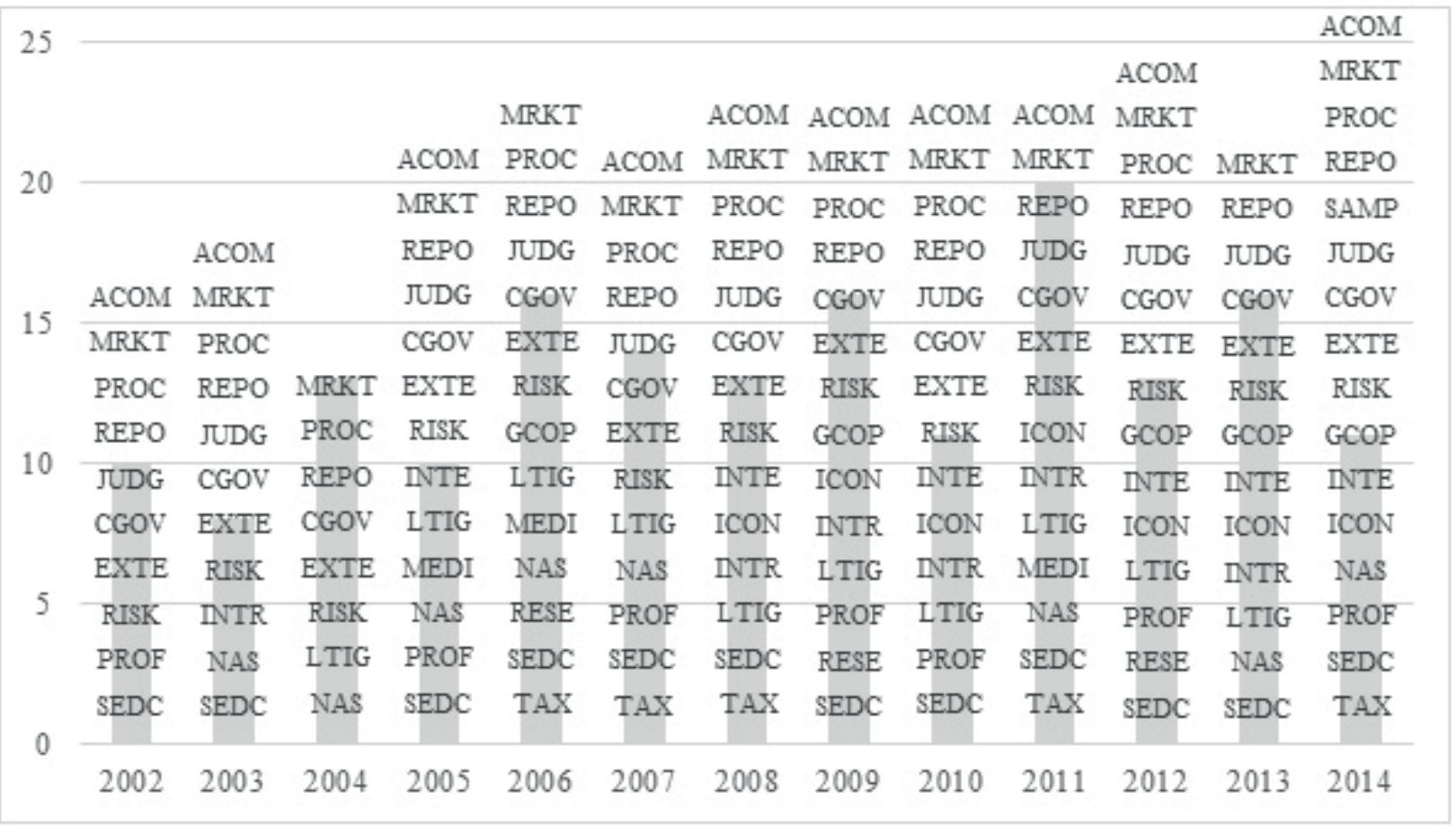

Figure 5 Production in volume (by theme) - Contemporary Accounting Research Note: Themes are described in the text.

Source: Developed by the authors.

Such results prove that Auditing: A Journal of Practice \& Theory, Accounting Review and Contemporary Accounting Research play an important role for research development in auditing, strengthening well-established and current themes in the area, with new thematic topics. These journals approach, because they disclose several themes in auditing, confirm the reasoning of Power (2003) in favor of avoiding being hostage to professional concepts in auditing. In that effort, journals shall be able to publish concepts not oriented to the auditors' professional practice and that were not identified in the studies of Smith and Krogstad (1984, 1988, 1991), Lesage and Wechtler (2012), and Maijoor, Meuwissen, and Quadackers (2000).

\subsection{Thematic Association}

Table 4 presents the association between themes by a statistic incidence, something not yet seen in audit researches. In the horizontal analysis, the three highest percentages were evidenced by relating one theme to others using shading the off effect, illustrating the reduction of the theme relation to other themes (darker for higher quantity), using the seven major themes in auditing as guidelines (Table 3 ). The three most important associations are presented here (decreasing order):

- Audit report \& financial statement users (REPO) the results show that researchers, while performing studies about audit report \& financial statement 
users, associate them mainly to corporate governance (CGOV) in $38 \%$ of cases, then to audit market (MRKT; 29\%) and, finally, to external audit (EXTE; 23\%).

- Corporate governance (CGOV) - the second most identified theme in auditing is related mainly to audit report \& financial statement users (REPO; $40 \%$ ), next to audit market (MRKT; 29\%), and further to socio-economic data of the company (SEDC; 22\%);

- Audit market (MRKT) - as to audit market, researchers relate it to external audit (EXTE; 39\%), audit report \& financial statement users (REPO; $38 \%$ ), and socio-economic data of the company (SEDC; 25\%), in this order;

- External audit (EXTE) - this is one of the new themes that emerged from this research and is related to audit market (MRKT; 39\%), audit report \& financial statement users (REPO; 30\%), and corporate governance (CGOV; 22\%);

- Socio-economic data of the company (SEDC) another new theme and related to the themes: corporate governance (CGOV; 39\%), audit market (MRKT; 36\%), and audit report \& financial statement users (REPO; 34\%);
- International regulation (INTR) - when researchers write about INTR, they also refer to audit report \& financial statement users (REPO; $36 \%$ ), corporate governance (CGOV; $22 \%$ ), and socio-economic data of the company (SEDC; $20 \%)$;

- Fraud risk \& audit risk (RISK) - a very important theme for stakeholders and usually associated to scholars of audit report \& financial statement users (REPO; 24\%), audit market (MRKT; 23\%), and external audit (EXTE; 21\%), respectively. Corporate governance (CGOV) emerges as being seven times the most associated between others. This means that when researchers write about auditing they are not only worried about technical themes or legal matters, but they are also trying to understand aspects related to corporate governance concerning the auditors' clients.

Corporate governance (CGOV) emerges as being seven times the most associated between others. This means that when researchers write about auditing they are not only worried about technical themes or legal matters, but they are also trying to understand aspects related to corporate governance concerning the auditors' clients. 


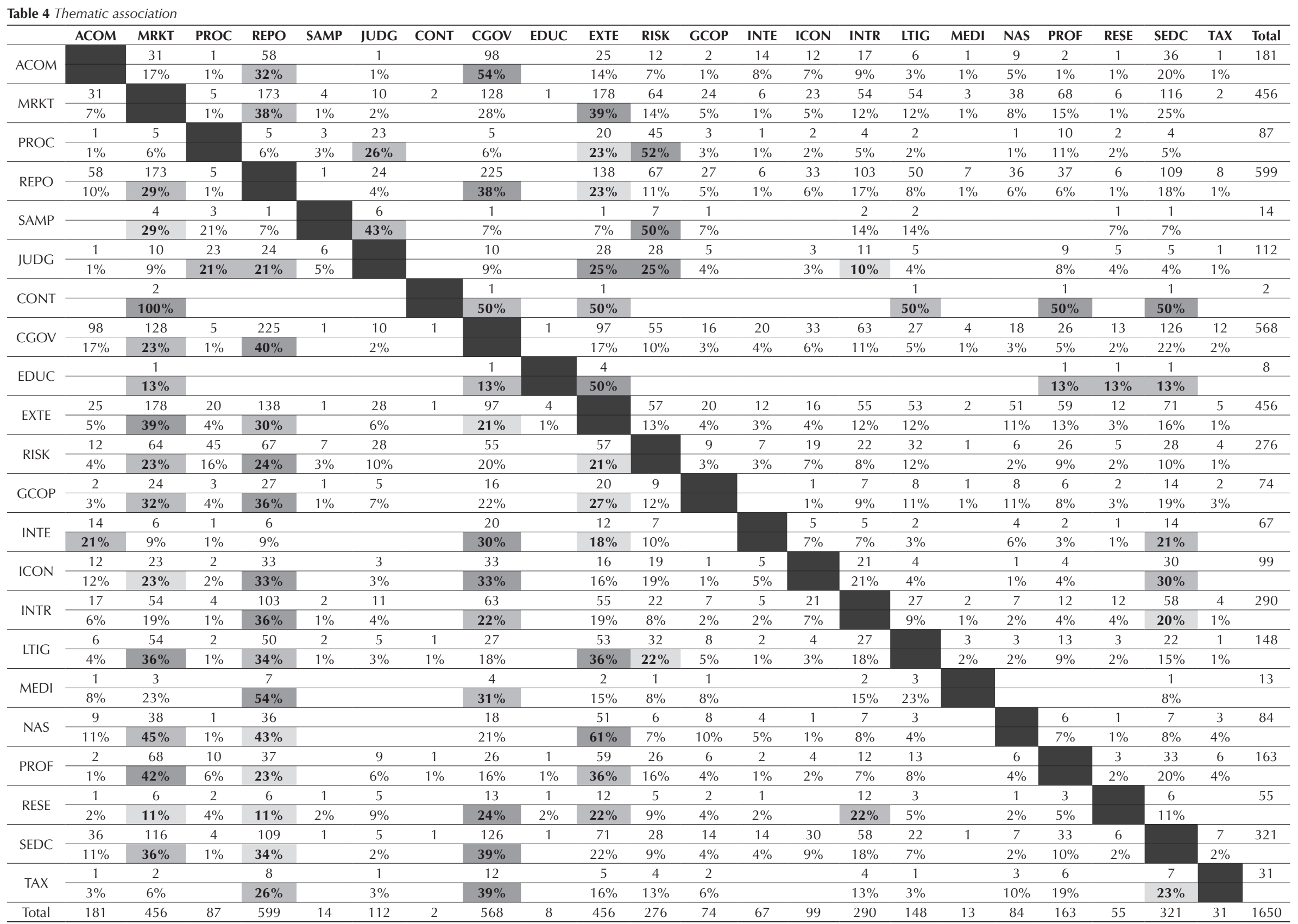




\section{CONCLUSION, LIMITATIONS, AND FUTURE RESEARCH}

As part of the basis for the development in auditing, themes on this matter, during more than three decades of study, have been of great importance to the academic and professional development of this area worldwide. However, because of important facts in the contemporary world, which affect considerably the studies related to auditing, as the SOX, it has been observed that previous researches are outdated, other than their relevance to the academic and professional universe.

This research aims to correct this gap by studying the themes about auditing after the post-SOX period, identifying the changes occurred in the thematic areas and relating their association in auditing.

The results placed seven established themes in auditing, which are audit market, audit report \& financial statement users, corporate governance, fraud risk \& audit risk, international regulation, liability \& litigation, and non-audit services. Despite the changes that took place after the period of the SOX enactment, these themes continued being part of the researches. They were tracked in every year of the sampling and there was an evolution in their representativeness percentages when compared to previous studies.

After the SOX period, the results presented eight themes, which keep losing strength in auditing researches. They are audit procedures, audit sampling, auditor's judgment, auditor-auditee contract, education, goingconcern opinion, profession, and tax audit. The reason for their decline is the fact that their representativeness percentages have decreased in the results presented in comparison to the existing literature.

As a new element, the current study managed to evidence the seven themes that emerged after the SOX enactment. These themes were not indexed as auditing themes in former researches in academic literature. They are audit committee, external audit, internal audit, internal control, media coverage in accounting, research, and socio-economic data of the company.

Another important contribution of this research was identifying the thematic associations in auditing. Now researchers will improve their understanding of what really occurs in the investigations when they acknowledge, for example, that corporate governance is not only the second most distinguished theme in auditing, but also the most related to other themes. It is a demonstration that even more than understanding technical and legal aspects in auditors' profession, researchers are concerned about factors that affect the auditors' clients.

Finally, this study managed to accomplish the objectives proposed, bringing up to date the existing themes in auditing literature and presenting the existing connections between them. However, it has limitations as well as every other study. The first of them is having used only publications from Web of Science as its sample size. Another limitation is due to the quantity of scientific journals analyzed which were limited only to 21 , hiding from its results the journals which had less than $1 \%$ of their publications analyzed.

We emphasize that the results found here are not definitive. Therefore, it is necessary to carry out new researches in order to check if the factors previously mentioned will remain valid in the future. It is of great importance that conferences should debate the reason for the possible lack of interest of researchers about the themes indexed, in this study, as declining. By the passage of the years, it is common to have establishment, declining, and emerging of new themes. Nevertheless, in benefit of auditing history, researches and professionals of the area must assess these changes and try to add a new profile to the themes of the past, so these thematic areas will be remembered and not forgotten in a state of scientific limbo.

In conclusion, we question ourselves if the themes rated as established will remain in the future the same way they were presented in the period of this research; and if the emerging themes will become established or will decline just as a scientific short trend from that time. Also, if the declining themes will have the strength to emerge again or if they will not be part of the scientific journals anymore. At last, we question if by the SOX enactment the themes in evidence were the only ones to have the merit to be published, because they were not recurrent in scientific journals. Certainly those are quests that researchers will be further concerned to answer in their new studies, in order to give dynamism and progress to auditing researches in the future. 


\section{REFERENCES}

Alic, M., \& Rusjan, B. (2011). A model for measuring an ISO 9000 internal audit outcome. African Journal of Business Management, 5(13), 5388-5404.

Allen, A., \& Woodland, A. (2010). Education requirements, audit fees, and audit quality. Auditing: $A$ Journal of Practice \& Theory, 29(2), 1-25.

Amin, K., Krishnan, J., \& Yang, J. S. (2014). Going concern opinion and cost of equity. Auditing: A Journal of Practice \& Theory, 33(4), 1-39.

Andon, P., \& Free, C. (2014). Media coverage of accounting: the NRL salary cap crisis. Accounting Auditing \& Accountability Journal, 27(1), 15-47.

Athanasakou, V., \& Hussainey, K. (2014). The perceived credibility of forward-looking performance disclosures. Accounting and Business Research, 44(3), 227-259.

Azizkhani, M., Monroe, G. S., \& Shailer, G. (2010). The value of Big 4 audits in Australia. Accounting and Finance, 50(4), 743-766.

Badolato, P. G., Donelson, D. C., \& Ege, M. (2014). Audit committee financial expertise and earnings management: the role of status. Journal of Accounting \& Economics, 58(2-3), 208-230.

Bedard, J. C., \& Graham, L. (2011). Detection and severity classifications of Sarbanes-Oxley Section 404 internal control deficiencies. Accounting Review, 86(3), 825-855.

Bhattacharjee, S., Moreno, K. K., \& Riley, T. (2012). The interplay of interpersonal affect and source reliability on auditors' inventory judgments. Contemporary Accounting Research, 29(4), 1087-1108.

Bigus, J. (2012). Vague auditing standards and ambiguity aversion. Auditing: A Journal of Practice \& Theory, 31(3), 23-45.

Blay, A. D., Geiger, M. A., \& North, D. S. (2011). The auditor's going-concern opinion as a communication of risk. Auditing: A Journal of Practice \& Theory, 30(2), 77-102.

Bonner, S. E., Hesford, J. W., Van der Stede, W. A., \& Young, S. M. (2006). The most influential journals in academic accounting. Accounting Organizations and Society, 31(7), 663-685.

Boone, J. P., Khurana, I. K., \& Raman, K. K. (2011). Litigation risk and abnormal accruals. Auditing: $A$ Journal of Practice \& Theory, 30(2), 231-256.

Cahan, S., Emanuel, D., Hay, D., \& Wong, N. (2008). Nonaudit fees, long-term auditor - client relationships and earnings management. Accounting and Finance, 48(2), 181-207.

Caramanis, C. V. (2005). Rationalisation, charisma and accounting professionalisation: perspectives on the intra-professional conflict in Greece, 1993-2001. Accounting Organizations and Society, 30(3), 195-221.

Carcello, J. V., Hermanson, D. R., \& Ye, Z. X. (2011). Corporate governance research in accounting and auditing: insights, practice implications, and future research directions. Auditing: A Journal of Practice \& Theory, 30(3), 1-31.

Carcello, J. V., \& Li, C. (2013). Costs and benefits of requiring an engagement partner signature: recent experience in the United Kingdom. Accounting Review, 88(5), 1511-1546.

Carcello, J. V., Neal, T. L., Palmrose, Z. V., \& Scholz, S. (2011). CEO Involvement in selecting board members, audit committee effectiveness, and restatements. Contemporary Accounting Research, 28(2), 396-430.

Carrera, N., \& Carmona, S. (2013). Educational reforms set professional boundaries: the Spanish audit function, 1850-1988. Abacus, 49(1), 99-137.

Carson, E., \& Fargher, N. (2007). Note on audit fee premiums to client size and industry specialization. Accounting and Finance, 47(3), 423-446.

Carson, E., Redmayne, N. B., \& Liao, L. (2014). Audit market structure and competition in Australia. Australian Accounting Review, 24(4), 298-312.

Chen, K. Y., Elder, R. J., \& Hung, S. M. (2014). Do postrestatement firms care about financial credibility? Evidence from the pre- and post-SOX eras. Journal of Accounting and Public Policy, 33(2), 107-126.

Cheng, K. W. (2011). Does thinking change with roles? A dynamic process of e-learners, e-learning managers and leaders in international accounting firms. African Journal of Business Management, 5(8), 3229-3243.

Chi, W. C., Dhaliwal, D., Li, O. Z., \& Lin, T. H. (2013). Voluntary reporting incentives and reporting quality: evidence from a reporting regime change for private firms in Taiwan. Contemporary Accounting Research, 30(4), 1462-1489.

Chin, C. L., Yao, W. R., \& Liu, P. Y. (2014). Industry audit experts and ownership structure in the syndicated loan market: at the firm and partner levels. Accounting Horizons, 28(4), 749-768.

Choi, J. H., Choi, S., Hogan, C. E., \& Lee, J. (2013). The effect of human resource investment in internal control on the disclosure of internal control weaknesses. Auditing: A Journal of Practice \& Theory, 32(4), 169199.

Choi, J. H., Kim, J. B., Liu, X. H., \& Simunic, D. A. (2008). Audit pricing, legal liability regimes, and Big 4 premiums: theory and cross-country evidence. Contemporary Accounting Research, 25(1), 55-99.

Choi, J. H., Kim, J. B., Qiu, A. A., \& Zang, Y. (2012). Geographic proximity between auditor and client: how does it impact audit quality? Auditing: A Journal of Practice \& Theory, 31(2), 43-72.

Choi, Y. K., Han, S. H., \& Lee, S. (2014). Audit committees, corporate governance, and shareholder wealth: evidence from Korea. Journal of Accounting and Public Policy, 33(5), 470-489. 
Cianci, A. M., \& Bierstaker, J. L. (2009). The impact of positive and negative mood on the hypothesis generation and ethical judgments of auditors. Auditing: A Journal of Practice \& Theory, 28(2), 119-144.

Clatworthy, M. A., \& Peel, M. J. (2013). The impact of voluntary audit and governance characteristics on accounting errors in private companies. Journal of Accounting and Public Policy, 32(3), 1-25.

Cohen, A., \& Sayag, G. (2010). The Effectiveness of internal auditing: an empirical examination of its determinants in Israeli organisations. Australian Accounting Review, 20(3), 296-307.

Conroy, S. J., Emerson, T. L. N., \& Pons, F. (2010). Ethical attitudes of accounting practitioners: are rank and ethical attitudes related? Journal of Business Ethics, 91(2), 183-194.

Cram, D. P., Karan, V., \& Stuart, I. (2009). Three threats to validity of choice-based and matched-sample studies in accounting research. Contemporary Accounting Research, 26(2), 477-516.

Cruz, S. C. S., \& Teixeira, A. A. C. (2010). The evolution of the cluster literature: shedding light on the regional studies - regional science debate. Regional Studies, 44(9), 1263-1288.

Dalton, D. W., Buchheit, S., \& McMillan, J. J. (2014). Audit and tax career paths in public accounting: an analysis of student and professional perceptions. Accounting Horizons, 28(2), 213-231.

De Franco, G., Gavious, I., Jin, J. Y., \& Richardson, G. D. (2011). Do Private company targets that hire Big 4 auditors receive higher proceeds? Contemporary Accounting Research, 28(1), 215-262.

De George, E. T., Ferguson, C. B., \& Spear, N. A. (2013). How much does IFRS cost? IFRS adoption and audit fees. Accounting Review, 88(2), 429-462.

De Waegenaere, A., Sansing, R. C., \& Wielhouwer, J. L. (2006). Who benefits from inconsistent multinational tax transfer-pricing rules? Contemporary Accounting Research, 23(1), 103-131.

Dee, C. C., Lulseged, A., \& Zhang, T. M. (2011). Client stock market reaction to $\mathrm{PCAOB}$ sanctions against a Big 4 auditor. Contemporary Accounting Research, 28(1), 263-291.

Desai, V., Roberts, R. W., \& Srivastava, R. (2010). An analytical model for external auditor evaluation of the internal audit function using belief functions. Contemporary Accounting Research, 27(2), 537-575.

Duan, C. H. (2011). Mapping the intellectual structure of modern technology management. Technology Analysis \& Strategic Management, 23(5), 583-600.

Elder, R. J., Akresh, A. D., Glover, S. M., Higgs, J. L., \& Liljegren, J. (2013). Audit sampling research: a synthesis and implications for future research. Auditing: A Journal of Practice \& Theory, 32, 99-129.

Elliott, J. A., Ghosh, A., \& Peltier, E. (2013). Pricing of Risky initial audit engagements. Auditing: A Journal of Practice \& Theory, 32(4), 25-43.
Ettredge, M. L., Li, C., \& Sun, L. (2006). The impact of SOX Section 404 internal control quality assessment on audit delay in the SOX era. Auditing: A Journal of Practice \& Theory, 25(2), 1-23.

Fetscherin, M., \& Usunier, J. C. (2012). Corporate branding: an interdisciplinary literature review. European Journal of Marketing, 46(5), 733-753.

Frederickson, J. R., \& Waller, W. (2005). Carrot or stick? Contract frame and use of decision-influencing information in a principal-agent setting. Journal of Accounting Research, 43(5), 709-733.

Free, C., Salterio, S. E., \& Shearer, T. (2009). The construction of auditability: MBA rankings and assurance in practice. Accounting Organizations and Society, 34(1), 119-140.

Garcia-Meca, E., \& Sanchez-Ballesta, J. P. (2009). Corporate governance and earnings management: a meta-analysis. Corporate Governance: An International Review, 17(5), 594-610.

Gu, Z. Y. (2013). Discussion of "Do political connections add value to audit firms? Evidence from IPO audits in China". Contemporary Accounting Research, 30(3), 922-924.

Gul, F. A., Zhou, G. G., \& Zhu, X. D. (2013). Investor protection, firm informational problems, Big $\mathrm{N}$ auditors, and cost of debt around the world. Auditing: A Journal of Practice \& Theory, 32(3), 1-30.

Habib, A. (2012). Non-Audit service fees and financial reporting quality: a meta-analysis. Abacus, 48(2), 214248.

Haw, I. M., Ho, S. S. M., \& Li, A. Y. (2011). Corporate governance and earnings management by classification shifting. Contemporary Accounting Research, 28(2), 517-553.

Humphrey, C., \& Miller, P. (2012). Rethinking impact and redefining responsibility. The parameters and coordinates of accounting and public management reforms. Accounting Auditing \& Accountability Journal, 25(2), 295-327.

Jensen, K. L., \& Payne, J. L. (2005). Audit procurement: managing audit quality and audit fees in response to agency costs. Auditing: A Journal of Practice \& Theory, 24(2), 27-48.

Johnson, E. N., Kuhn, J. R., Apostolou, B. A., \& Hassell, J. M. (2013). Auditor perceptions of client narcissism as a fraud attitude risk factor. Auditing: A Journal of Practice \& Theory, 32(1), 203-219.

Kanagaretnam, K., Krishnan, G. V., \& Lobo, G. J. (2009). Is the market valuation of banks' loan loss provision conditional on auditor reputation? Journal of Banking \& Finance, 33(6), 1039-1047.

Kaplan, S. E., \& Williams, D. D. (2013). Do going concern audit reports protect auditors from litigation? A simultaneous equations approach. Accounting Review, 88(1), 199-232.

Koh, H. P., Scully, G., \& Woodliff, D. R. (2011). The impact of cumulative pressure on accounting students' propensity to commit plagiarism: an experimental approach. Accounting and Finance, 51(4), 985-1005. 
Koh, K., Rajgopal, S., \& Srinivasan, S. (2013). Non-audit services and financial reporting quality: evidence from 1978 to 1980. Review of Accounting Studies, 18(1), 1-33.

Kostoff, R. N., Briggs, M. B., Rushenberg, R. L., Bowles, C. A., Icenhour, A. S., Nikodym, K. F., ... Pecht, M. (2007). Chinese science and technology - Structure and infrastructure. Technological Forecasting and Social Change, 74(9), 1539-1573.

Kostoff, R. N., Tshiteya, R., Bowles, C. A., \& Tuunanen, T. (2006). The structure and infrastructure of Finnish research literature. Technology Analysis \& Strategic Management, 18(2), 187-220.

Krishnan, J., Rama, D., \& Zhang, Y. (2008). Costs to comply with SOX Section 404. Auditing: A Journal of Practice \& Theory, 27(1), 169-186.

Krogstad, J. L., \& Smith, G. (2003). Assessing the influence of auditing: A Journal of Practice \& Theory: 19852000. Auditing: A Journal of Practice \& Theory, 22(1), 195-204.

Ladva, P., \& Andrew, J. (2014). Weaving a web of control "The promise of opportunity" and work-life balance in multinational accounting firms. Accounting Auditing \& Accountability Journal, 27(4), 634-654.

Lesage, C., \& Wechtler, H. (2012). An inductive typology of auditing research. Contemporary Accounting Research, 29(2), 487-504.

Li, Y. H. (2009). Shareholder litigation, management forecasts, and productive decisions during the initial public offerings. Journal of Accounting and Public Policy, 28(1), 1-15.

Lim, R. (2011). Are corporate governance attributes associated with accounting conservatism? Accounting and Finance, 51(4), 1007-1030.

Luippold, B. L., \& Kida, T. E. (2012). The impact of initial information ambiguity on the accuracy of analytical review judgments. Auditing: A Journal of Practice \& Theory, 31(2), 113-129.

Luypaert, M., \& Van Caneghem, T. (2014). Can auditors mitigate information asymmetry in M\&As? An empirical analysis of the method of payment in Belgian transactions. Auditing: A Journal of Practice \& Theory, 33(1), 57-91.

Lynch, A. L., Murthy, U. S., \& Engle, T. J. (2009). Fraud brainstorming using computer-mediated communication: the effects of brainstorming technique and facilitation. Accounting Review, 84(4), 1209-1232.

Maijoor, S., Meuwissen, R., \& Quadackers, L. (2000). The effects of national institutions on audit research: evidence from Europe and North America. European Accounting Review, 9(4), 569-587.

Mauldin, E. G., \& Wolfe, C. J. (2014). How do auditors address control deficiencies that bias accounting estimates? Contemporary Accounting Research, 31(3), 658-680.

Mennicken, A. (2008). Connecting worlds: the translation of international auditing standards into post-Soviet audit practice. Accounting Organizations and Society, 33(4-5), 384-414.
Napier, C. J. (2006). Accounts of change: 30 years of historical accounting research. Accounting Organizations and Society, 31(4-5), 445-507.

Nerur, S. P., Rasheed, A. A., \& Natarajan, V. (2008). The intellectual structure of the strategic management field: an author co-citation analysis. Strategic Management Journal, 29(3), 319-336.

Pike, B. J., Curtis, M. B., \& Chui, L. (2013). How does an initial expectation bias influence auditors' application and performance of analytical procedures? Accounting Review, 88(4), 1413-1431.

Porte, M. S., Saur-Amaral, I., \& Pinho, J. C. C. (2015). Audit research: a systematic literature review of published research on ISI Web of Science between 2002 and 2013. African Journal of Business Management, 9(4), 116-126.

Power, M. K. (2003). Auditing and the production of legitimacy. Accounting Organizations and Society, 28(4), 379-394.

Prawitt, D. F., Sharp, N. Y., \& Wood, D. A. (2012). Internal audit outsourcing and the risk of misleading or fraudulent financial reporting: did Sarbanes-Oxley get it wrong? Contemporary Accounting Research, 29(4), 1109-1136.

Rennie, M. D., Kopp, L. S., \& Lemon, W. M. (2010). Exploring trust and the auditor-client relationship: factors influencing the auditor's trust of a client representative. Auditing: A Journal of Practice \& Theory, 29(1), 279-293.

Robinson, D. (2008). Auditor independence and auditorprovided tax service: evidence from going-concern audit opinions prior to bankruptcy filings. Auditing: $A$ Journal of Practice \& Theory, 27(2), 31-54.

Saito, Y., \& McIntosh, C. S. (2010). The economic value of auditing and its effectiveness in public school operations. Contemporary Accounting Research, 27(2), 639-667.

Sarbanes-Oxley Act of 2002, of July 30, 2002. (2002, July 30). Retrieved from https://www.sec.gov/about/laws/ soa2002.pdf

Sharma, V. D., \& Iselin, E. R. (2012). The association between audit committee multiple-directorships, tenure, and financial misstatements. Auditing: $A$ Journal of Practice \& Theory, 31(3), 149-175.

Silva, S. T., \& Teixeira, A. A. C. (2009). On the divergence of evolutionary research paths in the past 50 years: a comprehensive bibliometric account. Journal of Evolutionary Economics, 19(5), 605-642.

Smith, G., \& Krogstad, J. L. (1984). Impact of sources and authors on auditing: A Journal of Practice and Theory: a citation analysis. Auditing: A Journal of Practice \& Theory, 4(1), 107-117.

Smith, G., \& Krogstad, J. L. (1988). A taxonomy of content and citations in auditing: A Journal of Practice and Theory. Auditing: A Journal of Practice \& Theory, 8(1), 108-117.

Smith, G., \& Krogstad, J. L. (1991). Sources and uses of auditing: A Journal of Practice and Theory's literature: 
the first decade. Auditing: A Journal of Practice o Theory, 10(2), 84-97.

Solomon, I., \& Trotman, K. T. (2003). Experimental judgment and decision research in auditing: the first 25 years of AOS. Accounting Organizations and Society, 28(4), 395-412.

Stephens, N. M., Summers, S. L., Williams, B., \& Wood, D. A. (2011). Accounting doctoral program rankings based on research productivity of program graduates. Accounting Horizons, 25(1), 149-181.

Tarr, J. A., \& Mack, J. (2013). Auditor obligations in an evolving legal landscape. Accounting Auditing \& Accountability Journal, 26(6), 1009-1026.

Trompeter, G., \& Wright, A. (2010). The world has changed - have analytical procedure practices? Contemporary Accounting Research, 27(2), 669-700.
Trompeter, G. M., Carpenter, T. D., Jones, K. L., \& Riley, R. A. (2014). Insights for research and practice: what we learn about fraud from other disciplines. Accounting Horizons, 28(4), 769-804.

Uysal, O. O. (2010). Business ethics research with an accounting focus: a bibliometric analysis from 1988 to 2007. Journal of Business Ethics, 93(1), 137-160.

Vermeer, T. E., Edmonds, C. T., \& Asthana, S. C. (2014). Organizational form and accounting choice: are nonprofit or for-profit managers more aggressive? Accounting Review, 89(5), 1867-1893.

Young, S. M., \& Peng, E. Y. (2013). An analysis of accounting frauds and the timing of analyst coverage decisions and recommendation revisions: evidence from the US. Journal of Business Finance \& Accounting, 40(3-4), 399-437. 